\title{
Wychowanie do życia wspólnotowego jako zadanie szkolnej lekcji religii w świetle polskich dokumentów oświatowych i katechetycznych
}

Dyskusje toczące się wokół lekcji religii w szkole ukazują szczególny charakter i swoistą wrażliwość tego przedmiotu na wszelkiego typu przeobrażenia dotykające życie społeczne. Religia w szkole bowiem to nie tylko przekaz wiedzy, przed szkolną katechezą stoją także konkretne zadania wychowawcze. Nie ulega też wątpliwości, że trudności związane z procesem wychowania dotyczą całej społeczności szkolnej, zaś jednym z trudnych zadań szkolnej lekcji religii jest wychowanie do życia we wspólnocie ${ }^{1}$. Odpowiedź na pytanie, w jakim wymiarze jest ono możliwe do zrealizowania w ramach szkolnej lekcji religii, wymaga na wstępie sprecyzowania samego pojęcia „wychowanie” oraz roli wspólnoty w wychowaniu religijnym. Następnie należy przedstawić zadania wychowawcze polskiej szkoły, wynikające ze znowelizowanej w 2009 roku podstawy programowej kształcenia ogólnego, bowiem kształtują one program wychowawczy szkoły. Na tym tle mogą być ukazane zadania wychowawcze, jakie dokumenty Kościoła stawiają przed szkolną lekcją religii. Dzięki temu ukazane zostaną perspektywy wychowania do życia wspólnotowego zgodnie z Podstawą programową katechezy Kościoła katolickiego w Polsce z 2010 roku.

\section{Wychowanie i wspólnota}

Wychowanie przebiega na tle innych procesów rozwoju człowieka, z których w tym kontekście istotny jest proces socjalizacji. Pojęcie „socjalizacja” wprowadził do naukowego dyskursu Emil Durkheim w 1910 roku. W szerokim rozumieniu

${ }^{1}$ Por. Kongregacja ds. Duchowieństwa, Dyrektorium ogólne o katechizacji, Rzym, 15 sierpnia 1997, 86 [dalej: DOK]. 
termin ten oznacza „kształtowanie osobowości społecznej” i „wchodzenie [jednostki] w kulturę" czy - inaczej - spontaniczne i niezamierzone przystosowanie się społeczne i kulturowe ${ }^{2}$.

Wąsko rozumiana socjalizacja jest procesem włączania jednostki w społeczeństwo, umożliwiającym integrację z nim, czyli zaadoptowanie przyjętego w danym społeczeństwie sposobu myślenia i odczuwania oraz zgodę na obowiązujący w nim system wartości, łącznie z powszechnie głoszonymi tam opiniami, przekonaniami, wierzeniami, ideami itp. ${ }^{3}$.

Proces ten dokonuje się w sposób spontaniczny. Jednostka ma w sobie trwałą zdolność i zarazem inklinację, by uczestniczyć w kulturze oraz społeczności, która ją otacza. Celnie precyzuje to pojęcie w kontekście działań wychowawczych Marian Śnieżyński:

uspołecznienie jest bowiem procesem dynamicznym, polegającym na wchodzeniu w coraz to nowe grupy i role społeczne, na uczeniu się ich, przechodzeniu od pełnienia ról wyuczonych do podejmowania nowych. Rolą wychowawców będzie czuwanie nad prawidłowością relacji interpersonalnych oraz przeciwdziałanie ewentualnym negatywnym wpływom grupy na jednostkę ${ }^{4}$.

Socjalizacja jest procesem pierwotnym wobec wychowania, a istota tego ostatniego sprowadza się do jej właściwego ukierunkowania i zapewnienia pozytywnych efektów. Uprzedniość i samoczynność procesu socjalizacji względem wychowania Wolfgang Brezinka ujmuje następująco:

Młodzież nie czeka na wychowanie, lecz spontanicznie uczy się tego wszystkiego, co uważa się za cenne i czym należy kierować się w życiu. Przez wychowanie można jedynie uzupełnić lub ewentualnie skorygować to, czego dzieci nauczyły się same, na podstawie własnych kontaktów ze środowiskiem ${ }^{5}$.

Z tego punktu widzenia ważne jest środowisko życia dzieci i młodzieży, w którym przebywają oni przed lub poza systematycznym i zaplanowanym procesem wychowania. Im bardziej jest ono spójne i uporządkowane, tym mniej później będzie działań korekcyjnych na rzecz pracy wspomagająco-kształtującej osobowość ucznia-wychowanka ${ }^{6}$.

\footnotetext{
${ }^{2}$ Por. M. Łobocki, Teoria wychowania w zarysie, Kraków 2009, s. 41.

${ }^{3}$ Tamże, s. 42.

${ }^{4}$ M. Śnieżyński, Cele ksztatcenia ogólnego w nauczaniu katechetycznym, „Katecheta” 2013, nr 3, s. 8 .

${ }^{5}$ W. Brezinka, Wychowanie i pedagogika w dobie przemian kulturowych, Kraków 2005, s. 12.

${ }^{6}$ Por. Ośrodek Rozwoju Edukacji, Jak tworzyć program wychowawczy szkoły - opis modelu. Poradnik dla szkót, oprac. T. Garstka, K. Leśniewska, Warszawa 2008, s. 19n.
} 
Wychowanie, podobnie jak socjalizacja, jest procesem adaptacji do obowiązujących norm postępowania. Niemniej, w odróżnieniu od niej, jest ono świadomą i celową interwencją w procesy socjalizacyjno-inkulturacyjne. Jest postępowaniem zamierzonym i zaplanowanym. Wychowanie jest próbą racjonalizacji dokonującego się wcześniej i samoczynnie procesu socjalizacji. Ma charakter intencjonalny, a wychowawca jest świadomy celów, jakie pragnie realizować w wyniku zorganizowanej działalności wychowawczej. Nie wszystko oczywiście da się zaplanować, gdyż równolegle nieustannie dokonuje się socjalizacja, obejmująca niezamierzone wpływy środowiska, środków masowego przekazu itd. Stąd też proces wychowania wymaga czasu, jest długotrwały, a ostatecznie, biorąc pod uwagę również samowychowanie, obejmuje całe życie człowieka. Wychowanie powinno także łączyć się z systematycznością․

Pierwotnym środowiskiem zarówno socjalizacji, jak i wychowania jest rodzina. W niej również rozpoczyna się proces rozwoju społeczno-moralnego młodego człowieka. Zdaniem W. Brezinki podstawowe przekonania duchowe i moralne człowieka najlepiej kształtują się w rodzinie i w tych wspólnotach, gdzie dziecko znajduje poczucie bezpieczeństwa, w wąskim kręgu bliskich mu ludzi, gdzie istnieją więzi uczuciowe, wspólna hierarchia wartości i dobre przykłady. Takich warunków nie zapewni żadna szkoła ${ }^{8}$.

Ze ściśle zaplanowanym procesem wychowania mamy jednak do czynienia w szkole. Zadaniem szkoły jest wspomaganie wychowawczej roli rodziny i przygotowanie każdego ucznia do samodzielnego wypełniania w przyszłości zadań rodzinnych i obywatelskich ${ }^{9}$. Wychowanie szkolne to

mądre towarzyszenie wychowankowi na drodze jego rozwoju i stwarzanie wychowawczego klimatu w środowisku szkolnym. Rozwój człowieka jest zjawiskiem naturalnym i samoistnym. Nauczyciel-wychowawca poprzez swoje wysiłki wydobywa to, co w młodym człowieku cenne, lecz jeszcze ukryte, wyzwala jego potencjał. Tak rozumiana praca wychowawcy raczej przypomina pracę ogrodnika, pochylającego się z troską nad powierzonymi jego opiece sadzonkami, aniżeli rzeźbiarza, urabiającego bezkształtny materiał według własnych lub narzuconych koncepcji ${ }^{10}$.

W zaplanowany proces wychowania włączona jest szkolna lekcja religii, pełniąc względem ucznia potrójną funkcję: informacyjną, formacyjną i wychowawczą ${ }^{11}$. W zakresie formacji celem nauczania religii w szkole jest umożliwienie wycho-

\footnotetext{
${ }^{7}$ Por. M. Łobocki, Teoria wychowania w zarysie, dz. cyt., s. 46, 52-56.

${ }^{8}$ Por. W. Brezinka, Wychowanie i pedagogika $w$ dobie przemian ..., dz. cyt., s. 33.

${ }^{9}$ Por. Ustawa o systemie oświaty z dnia 7 września 1991 r., Dz.U. z 2004 r. Nr 256, poz. 2572 z późn. zm.

${ }^{10}$ M. Cogiel, Korelacja nauczania religii z systemem wychowania szkolnego, [w:] Rodzina - szkoła-Kościót. Korelacja i dialog, red. P. Tomasik, Warszawa 2003, s. 118.

${ }^{11}$ Por. Konferencja Episkopatu Polski, Dyrektorium katechetyczne Kościoła katolickiego w Polsce, Kraków 2001, 37-53 [dalej: PDK].
} 
wankom poważnej konfrontacji z zagadnieniami sensu życia i ostatecznego celu człowieka, stworzenie możliwości podjęcia dojrzałej, wolnej i odpowiedzialnej decyzji co do rozwoju ich religijności oraz promowanie integrowania wiedzy religijnej z ich własnym dziedzictwem kulturowym ${ }^{12}$. W swej funkcji wychowawczej katecheza szkolna „ma na celu doprowadzenie wychowanków do koegzystencji i dialogu w społeczności religijnej i ideologicznie pluralistycznej oraz winna zmierzać do scalania wiary i kultury" "13. Wychowanie do życia wspólnotowego jako jedno z zadań katechezy jest zatem wielowymiarowe. Musi uwzględniać istnienie różnych społeczności, wspólnot, wśród których czołowe miejsca zajmują rodzina oraz naród jako wspólnoty naturalne, obok nich zaś występuje Kościół jako wspólnota nadprzyrodzona ${ }^{14}$. Zasadniczym celem wychowania jest kształtowanie „autentycznej wspólnoty chrześcijańskiej” (DOK 86) na poziomie naturalnym, jak i nadprzyrodzonym. Ma to prowadzić wychowanków do „odpowiedzi wiary na wezwanie Boga, który zbawia" (PDK 38), do odkrycia swej roli we wspólnocie, a także ma skłaniać do braterskich postaw, wśród których Dyrektorium ogólne o katechizacji wymienia: ducha prostoty i pokory, troskę o najmniejszych i o tych, którzy opuszczają wspólnotę Kościoła, braterskie upomnienie, wspólną modlitwę i wzajemne przebaczenie oraz postawy ekumeniczne (por. DOK 86). Kształtowanie autentycznej i przemieniającej relacji z Bogiem łączy się z wychowaniem moralnym (por. PDK 39-40), zaś w sam proces wychowawczy ma zostać włączona możliwość „przeżycia i doświadczenia wartości” (PDK 37), zwłaszcza gdy wychowankowie są jej pozbawieni w swoich wspólnotach rodzinnych. By to zadanie spełnić, przed katechetą i katechizowanymi stoi trudne wyzwanie stworzenia „wspólnoty katechetycznej", czyli środowiska rozwoju i kształtowania wiary, które nie opiera się wyłącznie na przekazie wiadomości religijnych (por. PDK 37).

Reasumując, wychowanie, w tym także kształtowanie wspólnoty, jest procesem delikatnym i trudnym do uchwycenia w jednoznaczne schematy. Domaga się postępowania według tych reguł, które sprzyjają rozwojowi każdego z wychowanków i właściwemu przebiegowi ich socjalizacji. Na zadania wychowawcze stawiane przed szkołą oraz przed szkolną lekcją religii warto spojrzeć, sięgając do najnowszych dokumentów określających kształt polskiego szkolnictwa.

12 „Formation: To propose a serious confrontation with the problems of meaning, of life and of a person's ultimate goals, with a view to enable the students towards a mature, free and responsible decision in the religious field and to foster the integration of religious knowledge in their own cultural patrimony". E. Alberich, J. Vallabajar, Communicating a faith that transforms. A handbook of fundamental catechesis, Bangalore 2004, s. 233.

${ }^{13}$ T. Panuś, Jaka katecheza dla wspótczesnego człowieka? [w:] Katechetyka i katecheza u progu XXI wieku, red. A. Kiciński, Poznań 2007, s. 431.

${ }^{14}$ Por. S. Dziekoński, Zadania wspótczesnej katechezy w dokumentach katechetycznych Kościoła w Polsce, [w:] Przestanie dokumentów katechetycznych Kościoła w Polsce, red. S. Dziekoński, Warszawa 2003, s. 115. 


\section{Cele wychowania szkolnego według podstawy programowej MEN z 2009 roku}

Zgodnie z założeniami reformy podstawy programowej w Polsce z 2009 roku działalność edukacyjna szkoły jest określona przez: szkolny zestaw programów nauczania, program wychowawczy szkoły oraz program profilaktyki, które łącznie tworzą spójną całość ${ }^{15}$. Wychowanie w szkole przebiega według przyjętego w danej placówce programu wychowawczego i profilaktycznego oraz idzie w parze z przekazem wiedzy. „Kształtowanie postaw, przekazywanie wiadomości oraz rozwijanie umiejętności stanowią wzajemnie uzupełniające się wymiary pracy nauczyciela. Aspekt wychowawczy pracy szkoły powinien być ujęty w formie szkolnego programu wychowawczego" ${ }^{16}$. Konstruowany w szkole program wychowawczy odzwierciedla cele i metody wychowania, jakimi kieruje się szkoła, i powinien być spójny z programami nauczania, ma uwzględniać kształtowanie postaw uczniów, mają go współtworzyć uczniowie, rodzice i nauczyciele. Ma być także osadzony w tradycji szkoły i lokalnej społeczności.

Opracowując program wychowawczy szkoły, trzeba uwzględnić wartości szczególnie ważne dla społeczności szkolnej, sformułować cele, określić zadania. Szkolny program wychowawczy winien obejmować:

- wypracowane przez społeczność szkolną wartości,

- tradycję szkolną, obyczaje i uroczystości,

- zagadnienia lub problemy, których rozwiązanie jest najważniejsze z punktu widzenia środowiska: uczniów, rodziców i nauczycieli ${ }^{17}$.

Stawiane w programie wychowawczym szkoły cele ogólne powinny uwzględniać m.in. „kreowanie i wskazywanie wzorców, przekazywanie wartości istotnych z punktu widzenia danej kultury, kształtowanie i wzmacnianie postaw prospołecznych" 18 . Realizacja tego programu pozostaje w związku ze zjawiskiem socjalizacji, powinna go wspierać i właściwie nim kierować. Z przedstawionej charakterystyki rodzi się jednak pytanie o podstawy aksjologiczne kształtowanego w ramach społeczności szkolnej programu wychowawczego.

Zauważa się, iż w koncepcji wychowania przyjętej w podstawie programowej z 2009 roku brakuje jasno określonego obszaru aksjologicznego, który ma nadawać kierunek

${ }^{15}$ Por. Podstawa programowa kształcenia ogólnego dla szkół podstawowych, Załącznik nr 2 do rozporządzenia MEN z dnia 23 grudnia 2008 r., Dz.U. z 2009 r., Nr 4, poz. 17; Podstawa programowa kształcenia ogólnego dla gimnazjów i szkół ponadgimnazjalnych, których ukończenie umożliwia uzyskanie świadectwa dojrzałości po zdaniu egzaminu maturalnego, Załącznik nr 4 do w/w rozporządzenia MEN z dnia 23 grudnia 2008.

${ }^{16} \mathrm{Z}$. Marciniak, O potrzebie reformy programowej ksztatcenia ogólnego, [w:] Ministerstwo Edukacji Narodowej, Podstawa programowa z komentarzami, t. 1: Edukacja przedszkolna i wczesnoszkolna, Warszawa 2009, s. 11.

${ }^{17}$ Por. tamże.

${ }^{18}$ Ośrodek Rozwoju Edukacji, Jak tworzyć program wychowawczy szkoły..., dz. cyt., s. 20. 
szkolnym wysiłkom wychowawczym ${ }^{19}$. Ze wskazań dotyczących konstruowania programu wychowawczego szkoły wynika, że kanon wartości stojący u podstaw tego programu jest wypadkową założeń podstawy programowej oraz potrzeb, zwyczajów i kultury środowiska lokalnego, w którym funkcjonuje szkoła. Z jednej strony, „nauczyciel, przed którym stoi zadanie wychowywania młodego człowieka, musi odnosić się zarówno do wiedzy dotyczącej prawidłowości rozwojowych, jak i pewnej wybranej, ustalonej koncepcji człowieka"20, z drugiej zaś, zgodnie z założeniami reformy, ustalenie ważnych wartości jest elementem niezbędnym i kluczowym w budowaniu programu wychowawczego. W wytycznych Ministerstwa Edukacji Narodowej czytamy, że „opracowując program wychowawczy szkoły, należy brać pod uwagę, jakie wartości są szczególnie ważne dla społeczności szkolnej”"21, co w praktyce oznacza, iż

ustalone przez społeczność szkolną wartości pozwalają na stworzenie pewnej wizji szkoły, sprzyjającej wychowaniu w zgodzie z tymi wartościami. Stanowią także podstawę dla stworzenia sylwetki absolwenta szkoły - czyli obrazu osoby kończącej szkołę, do którego osiągnięcia dążą wspólne oddziaływania rodziców i pracowników szkoły. Wymienione elementy stanowią niezbędny, początkowy element w tworzeniu programu wychowawczego. Są potrzebne do określenia celów ogólnych ${ }^{22}$.

Ustalenie kanonu wartości, które stoją u podstaw programu wychowawczego szkoły, stanowi zadanie, które mają wypracować wspólnie: rodzice, uczniowie oraz pracownicy szkoły, nadając kierunek oddziaływaniom wychowawczym placówki²3

Okazuje się zatem, że zgoda społeczności tworzącej daną szkołę w określonym czasie jest niezwykle istotna z punktu widzenia programu wychowawczego tej szkoły oraz że wszelkie przemiany i transformacje dokonujące się w tej społeczności będą miały wpływ na profil aksjologiczny tego programu, w granicach wyznaczonych przez normy prawne obowiązujące w szkolnictwie. Ważny jest wspólny kanon wartości podstawowych danej społeczności. Na ile możliwe jest osiągnięcie zgody co do tego kanonu wartości w zróżnicowanym środowisku szkolnym? Odpowiedź na to pytanie może stwarzać potencjalne trudności. Wskazuje na nie W. Brezinka, używając pojęcia „chaosu kulturowego”. Twierdzi on, iż coraz trudniej osiągnąć dzisiaj „trwały i podstawowy konsensus co do elementów kultury zewnętrznej i wewnętrznej, które dana wspólnota uważa za najważniejsze i najcenniejsze"24.

\footnotetext{
${ }^{19}$ Por. K. Misiaszek, Koncepcja nauczania religii katolickiej w publicznej szkole polskiej. Próba oceny, Warszawa 2010, s. 185n.

${ }^{20}$ Ośrodek Rozwoju Edukacji, Jak tworzyć program wychowawczy szkoły..., dz. cyt., s. 20.

${ }^{21}$ Szkoła przyjaźnie wymagajaca. Reforma programowa. Opis zmian potrzebnych w systemie edukacji. Projekt do konsultacji, Warszawa 2008, s. 19.

${ }^{22}$ Ośrodek Rozwoju Edukacji, Jak tworzyć program wychowawczy szkoły..., dz. cyt., s. 17n.

${ }^{23}$ Por. tamże, s. 18 n.

${ }^{24}$ W. Brezinka, Wychowanie i pedagogika w dobie przemian ..., dz. cyt., s. 11.
} 
Względna trwałość i zgoda danej społeczności co do jej aksjologicznych podstaw staje się, jego zdaniem, niezbędnym warunkiem skutecznej socjalizacji i zarazem wychowania. W sytuacji braku tej zgody wybór punktów orientacyjnych w zglobalizowanym świecie jest pozostawiony niedojrzałym jeszcze wychowankom, czyli innymi słowy: przypadkowi, ciekawości, rynkowi przyjemności czy tym czynnikom, które bazują na młodzieńczym braku doświadczenia ${ }^{25}$.

Reforma programowa polskiej szkoły z 2009 roku pozostawia w kwestii wychowania pewien margines wątpliwości dotyczący podstaw aksjologicznych. W treści podstawy programowej dla poszczególnych typów szkół czytamy, iż szkoła

kształtuje u uczniów postawy sprzyjające ich dalszemu rozwojowi indywidualnemu i społecznemu, takie jak: uczciwość, wiarygodność, odpowiedzialność, wytrwałość, poczucie własnej wartości, szacunek dla innych ludzi, ciekawość poznawcza, kreatywność, przedsiębiorczość, kultura osobista, gotowość do uczestnictwa w kulturze, podejmowania inicjatyw oraz do pracy zespołowej. W rozwoju społecznym bardzo ważne jest kształtowanie postawy obywatelskiej, postawy poszanowania tradycji i kultury własnego narodu, a także postawy poszanowania dla innych kultur i tradycji ${ }^{26}$.

Idąc tropem W. Brezinki, powyższe cele można zaliczyć do formalnych celów wychowania. Te jednak, jego zdaniem, same w sobie nie są wystarczające. Domagają się uzupełnienia poprzez cele materialne, czyli konkretny zasób wiedzy, umiejętności, wiary religijnej, przekonań moralnych, koncepcji politycznych nabywanych przez ucznia, co zapewnia mu właściwą orientację i integruje wspólnotę. Wśród ideałów wychowania szkolnego wspomniany autor wymienia takie zalety uczniowskie, jak: pilność, umiłowanie porządku, punktualność, posłuszeństwo, samodyscyplina, asceza; obowiązki wobec drugiego człowieka i wobec wspólnoty: solidarność, poszanowanie prawa, gotowość do służby, zakaz używania siły, troskę o pokój; pielęgnowanie dobrych przywiązań: do instytucji małżeństwa, rodziny, wspólnot ideologicznych czy religijnych oraz zdrową świadomość narodową. Takie sformułowanie celów ogólnych w dużo większym stopniu domaga się od wychowanków emocjonalnego przywiązania do wybranych, wartościowych elementów kultury (w formie poglądów, nastawień, postaw, przekonań i zainteresowań) kosztem innych, a zatem wymaga podjęcia decyzji ${ }^{27}$.

Formalne cele wychowania odnajdujemy w wymaganiach szczegółowych podstawy programowej z 2009 roku, odnoszących się do poszczególnych przedmiotów ${ }^{28}$.

${ }^{25}$ Por. tamże, s. $11-13$.

${ }^{26}$ Por. Podstawa programowa kształcenia ogólnego dla szkół podstawowych, Załącznik nr 2 do rozporządzenia MEN z dnia 23 grudnia 2008 r., Dz.U. z 2009 r., Nr 4, poz. 17.

${ }^{27}$ Por. W. Brezinka, Wychowanie i pedagogika w dobie przemian ..., dz. cyt., s. 16, 25-27, 30n, 70-76.

${ }^{28}$ Przykładowo: wśród celów edukacji społecznej w kl. I-III szkoły podstawowej znajdujemy następujący zapis: „Uczeń kończący klasę III: odróżnia dobro od zła, stara się być sprawiedliwym i prawdomównym; nie krzywdzi słabszych i pomaga potrzebującym, identyfikuje się ze swoją rodziną 
Dlatego obawy, jakoby obowiązująca podstawa programowa nie czyniła próby aksjologicznego ukierunkowania edukacji, zakładając pewien rodzaj konformizmu etycznego przyjmowanego w imię zasad poprawności politycznej ${ }^{29}$, wydają się o tyle uzasadnione, o ile wymagania ogólne wychowania szkolnego w poprzedniej podstawie programowej z 2002 roku wyraźniej wskazywały na wartości stojące u podstaw polskiej edukacji szkolnej ${ }^{30}$.

Na pozytywną ocenę zasługują wskazania odnoszące się do konstrukcji programu wychowawczego polskiej szkoły, mówiące że jednym z ważnych czynników dla prawidłowego funkcjonowania jednostki w społeczeństwie jest podtrzymywanie tradycji poprzez wspólne obchodzenie świąt i uroczystości. Dlatego na liście obchodzonych w środowisku danej szkoły świąt i uroczystości nie powinno zabraknąć tych, które dla członków danej społeczności są ważne. Chodzi tu o święta historyczne, kalendarzowe, religijne, rodzinne i lokalne, które należy wykorzystać w aspekcie wychowawczym $^{31}$. „Jeśli komuś zależy, aby młodzież umiała żyć i zachowała zdrowego ducha, będzie troszczył się o jej zakorzenienie w dobrach tradycji”" ${ }^{32}$.

Wychowanie rozumiane jako wprowadzenie do wspólnoty, społeczeństwa powinno się odbywać w oparciu o wartości, co do których istnienia dana społeczność jest zdecydowanie przekonana i zgodna. Skuteczność tak rozumianego wychowania w dużej mierze zależy od kondycji tej społeczności w zakresie zachowania względnie trwałej stabilności w przyjmowanych przez nią zasadach i normach funkcjonowania. Młody człowiek może wtedy odnaleźć własny punkt odniesienia w kreowaniu swej tożsamości, mając możliwość zakorzenienia w tej konkretnej tradycji i postrzeganiu świata. Inaczej będzie czuł się wyobcowany, a proces wychowania pozostanie niedokończony. W jaki zatem sposób w takie rozumienie programu wychowawczego

i jej tradycjami, zna prawa ucznia i jego obowiązki, respektuje je”. Por. Podstawa programowa kształcenia ogólnego dla szkół podstawowych, Załącznik nr 2 do rozporządzenia MEN z dnia 23 grudnia 2008 r., Dz.U. z 2009 r., Nr 4, poz. 17. W podstawie programowej dla szkół ponadgimnazjalnych w treściach nauczania języka polskiego odnajdujemy (podobnie jak w gimnazjum) dział zatytułowany Wartości i wartościowanie, a w nim tak określone wymagania szczegółowe: uczeń „dostrzega związek języka z wartościami, rozumie, że język podlega wartościowaniu, (np. język jasny, prosty, zrozumiały, obrazowy, piękny), jest narzędziem wartościowania, a także źródłem poznania wartości (utrwalonych w znaczeniach nazw wartości, takich jak: dobro, prawda, piękno; wiara, nadzieja, miłość; wolność, równość, braterstwo; Bóg, honor, ojczyzna; solidarność, niepodległość, tolerancja)". Podstawa programowa kształcenia ogólnego dla gimnazjów i szkół ponadgimnazjalnych, których ukończenie umożliwia uzyskanie świadectwa dojrzałości po zdaniu egzaminu maturalnego, Załącznik nr 4 do rozporządzenia MEN z dnia 23 grudnia 2008 r., Dz.U. z 2009 r., Nr 4, poz. 17.

${ }^{29}$ Por. K. Misiaszek, Koncepcja nauczania religii katolickiej..., dz. cyt., s. 185.

${ }^{30}$ Por. Podstawa programowa kształcenia ogólnego dla szkół podstawowych i gimnazjów, Załącznik nr 2 do Rozporządzenia MENiS z dnia 26 lutego 2002 r., Dz.U. z 2002 r., Nr 51, poz. 458. Powtarza ona w omawianej kwestii zapisy z poprzedniej podstawy programowej z 2001 roku.

${ }^{31}$ Por. Ośrodek Rozwoju Edukacji, Jak tworzyć program wychowawczy szkoły ..., dz. cyt., s. 25-29.

${ }^{32} \mathrm{~W}$. Brezinka, Wychowanie i pedagogika $w$ dobie przemian ..., dz. cyt., s. 13. 
szkoły wpisuje się zadanie wychowania do życia wspólnotowego, stawiane przed nauczaniem religii i katechezą Kościoła?

\section{Lekcja religii w trosce o tożsamość i postawę dialogu}

Rozważymy tę kwestię, prezentując najpierw zadania wychowawczo-socjalizacyjne, stawiane katechezie przez dokumenty Kościoła pod kątem ich włączenia w realizację programu wychowawczego szkoły. W znacznej mierze będą one dotyczyły wspólnot naturalnych.

W preambule obowiązującej w Polsce ustawy o systemie oświaty czytamy:

Nauczanie i wychowanie - respektując chrześcijański system wartości - za podstawę przyjmuje uniwersalne zasady etyki. Kształcenie i wychowanie służy rozwijaniu u młodzieży poczucia odpowiedzialności, miłości ojczyzny oraz poszanowania dla polskiego dziedzictwa kulturowego, przy jednoczesnym otwarciu się na wartości kultur Europy i świata ${ }^{33}$.

Wskazuje się zatem na potrzebę sięgania do chrześcijaństwa celem kształtowania właściwego profilu etycznego nauczania i wychowania. Ukazuje się też znaczenie patriotyzmu, rolę tradycji i kultury narodowej oraz jej usytuowania na tle kultur Starego Kontynentu i szerzej - na tle kultur świata.

W oparciu o zawarty przez Polskę konkordat ze Stolicą Apostolską oraz wspomnianą ustawę o systemie oświaty lekcja religii stanowi integralną część systemu edukacji i wychowania w szkole. Pełni rolę kształtującą tożsamość społeczną i indywidualną wychowanków, dając im również zasady odniesienia do innych wspólnot - rodziny, społeczeństwa, państwa (narodu) oraz innych wyznań chrześcijańskich i religii (por. DOK 86). Rodzina i naród to społeczności naturalne, a lekcja religii ma na celu umacnianie i uzdrawianie więzi rodzinnych zarówno w odniesieniu do rodziców lub rodzeństwa, jak i do najstarszych członków rodziny ${ }^{34}$. Przygotowuje także do życia we wspólnocie narodu, przekazując prawdę o jego historii - te treści pojawiają się na trzecim i czwartym etapie edukacyjnym ${ }^{35}$.

Konfesyjna lekcja religii prowadzona w środowisku szkolnym posiada wielopłaszczyznowy charakter z uwagi na zróżnicowanie przekonań jej adresatów. Dla uczniów wierzących jest to pogłębianie i umacnianie swej tożsamości; dla uczniów poszukujących lub wątpiących - próba znalezienia właściwego punktu oparcia w kształtowaniu swego charakteru i światopoglądu. Dla uczniów niewierzących

${ }^{33}$ Ustawa o systemie oświaty z dnia 7 września 1991 r., Dz.U. z 2004 r., Nr 256, poz. 2572 z późn. zm.

${ }^{34} \mathrm{~W}$ szczególności te tematy są omawiane w szkołach ponadgimnazjalnych. Por. Konferencja Episkopatu Polski, Podstawa programowa katechezy Kościoła katolickiego w Polsce, Kraków 2010, [dalej: PPK]., s. 78.

${ }^{35}$ Por. tamże, s. 56n, 76n. 
zaś - zapoznanie się z istotą chrześcijaństwa, co może stanowić dla nich punkt orientacyjny w pluralistycznej przestrzeni współczesności (por. DOK 75). Dzięki takiemu zróżnicowaniu szkolna lekcja religii wpisuje się w kształtowanie postaw uczniów w procesie kształcenia ogólnego w polskiej oświacie, z których warto tu przywołać: poczucie własnej wartości, szacunek dla innych ludzi, kulturę osobistą, gotowość do uczestnictwa w kulturze, kształtowanie postawy obywatelskiej, postawy poszanowania tradycji i kultury własnego narodu, a także poszanowanie innych kultur i tradycji ${ }^{36}$. Nie można zatem uznać, że religia jest prowadzona wyłącznie po to, by wcielać jej uczestników do wspólnoty Kościoła. Posiada cele zbieżne z programem wychowawczym szkoły. Cele te określa Podstawa programowa katechezy Kościoła katolickiego w Polsce z 2010 roku, która została opracowana, by dostosować założenia nauczania religii do zmian zachodzących w strukturze programów nauczania w polskiej szkole ${ }^{37}$.

W społeczeństwie pluralistycznym konieczne staje się wychowanie do pokojowego współżycia i do dialogu, zwłaszcza pomiędzy przedstawicielami różnych kultur i odmiennych przekonań religijnych. Szkoła może być uprzywilejowanym miejscem dla prowadzenia tego typu działań edukacyjnych i wychowawczych ${ }^{38}$. Ważnym zadaniem na tym tle jest wychowanie do współpracy ekumenicznej (por. DOK 86). Ta współpraca może odbywać się w dziedzinie troski o ludzką godność, pokój, usuwanie nierówności społecznych, uobecnianie chrześcijaństwa w nauce i sztuce czy innych działaniach inspirowanych nauką Ewangelii ${ }^{39}$. Te zagadnienia są obecne w wymaganiach szczegółowych podstawy programowej katechezy dla gimnazjum $^{40}$ oraz dla szkół ponadgimnazjalnych ${ }^{41}$.

Powiązanie wiary i kultury oraz kształtowanie tożsamości religijnej jednostki w warunkach życia społecznego, a także możliwość koegzystencji w pokojowym dialogu z przedstawicielami innych przekonań religijnych i światopoglądów to, jak się wydaje, podstawowe zadania wychowawcze edukacji religijnej w szkole w korelacji z programem wychowawczym szkoły. Według nowej podstawy programowej katechezy po drugim etapie edukacyjnym uczeń rozpoznaje swoje obowiązki wobec najbliższego otoczenia, wartościuje zjawiska społeczno-religijne na poziomie społeczności szkolnej i lokalnej, przyjmuje postawę odpowiedzialności za innych. W trakcie trzeciego etapu nabywa umiejętności względnie stałych zachowań, umotywowanych emocjonalnie wartościami najwyższymi; potrafi wskazać inicjatywy

\footnotetext{
${ }^{36}$ Por. Podstawa programowa kształcenia ogólnego dla szkół podstawowych, Załącznik nr 2 do rozporządzenia MEN z dnia 23 grudnia 2008 r., Dz.U. z 2009 r., Nr 4, poz. 17.

${ }^{37}$ Por. PPK, s. 12, 14.

${ }^{38}$ E. Alberich, Katecheza dzisiaj. Podręcznik katechetyki fundamentalnej, Warszawa 2003, s. 248.

${ }^{39}$ Por. Jan Paweł II, enc. Ut unum sint, 25 maja 1995, 74n, 82.

${ }^{40}$ Związek między chrześcijaństwem a dziedzictwem antycznym, problematyka stosunków państwa i Kościoła itd. Por. PPK, s. 56n.

${ }^{41}$ Por. tamże, s. 76n.
} 
ekumeniczne $^{42}$. Jest to więc realizacja kształtowania prawdziwego człowieczeństwa ${ }^{43}$, nie wyczerpuje jednak treści zadania wychowania do życia wspólnotowego, jakie przed katechezą stawia Dyrektorium ogólne o katechizacji. Rzymskie Dyrektorium wskazuje, że podjęcie decyzji o życiu wiarą domaga się uzupełnienia i podtrzymywania poprzez katechezę w kontekście wspólnotowym (por. DOK 75). To oznacza, że pełną skuteczność wychowawczą lekcja religii osiąga tylko w ramach wspólnoty wierzących, czyli wspólnoty nadprzyrodzonej.

\section{Lekcja religii w służbie wspólnoty Kościoła}

Od chwili ponownego wprowadzenia lekcji religii do polskich szkół wielokrotnie podejmowano w naszym kraju refleksję na ten temat, wyrażając przekonanie, iż klasa szkolna powinna stawać się miejscem tworzenia wspólnoty religijnej, która następnie znajdzie środowisko dla swego dalszego rozwoju w ramach duszpasterstwa parafialnego. Podkreślano, iż katecheci winni traktować szkolne nauczanie religii jako sposób na wprowadzenie ucznia w życie parafii czy do ruchów religijnych ${ }^{44}$.

Obserwatorzy edukacji religijnej w Europie zwracają uwagę, że w środowisku szkolnym nie będzie możliwa pełna realizacja zadania wychowania do życia wspólnotowego:

zarówno w przypadku nauczania wielkich religii, jak i sposobów wyrażania religijności przez uczniów - trzeba podkreślić na wstępie, że szkoły w Europie są głęboko zsekularyzowane w swoich programach, w swoich celach i metodach, jak też pod względem pracującego w nich personelu i uczniów ${ }^{45}$.

Podobny obraz kreśli w odniesieniu do szkół w Polsce Kazimierz Misiaszek, uważając że szkoła może nie być zainteresowana wprowadzaniem elementów ewangelizacyjnych do nauczania religii z obawy przed potraktowaniem jej jako miejsca wychowawczej działalności Kościoła. „Ponadto edukacja, poddawana określonym rodzajom wpływów ze strony Unii Europejskiej, będzie raczej przestrzegać norm w niej tworzonych, zwykle o charakterze liberalnym, niż otwierać się na racje

42 Tamże, s. 40, 42, 52, 57.

${ }^{43}$ Por. T. Panuś, Wstęp, [w:] Katecheza w Roku Kapłańskim. Materiały z Sierpniowych Dni Katechetycznych w Archidiecezji Krakowskiej w roku 2009, red. T. Panuś, Kraków 2009, s. 9.

${ }^{44}$ Por. K. Misiaszek, Koncepcja nauczania religii katolickiej..., dz. cyt., s. 194-196.

$45,[\ldots]$ tant au plan de l'enseignement des grandes religions qu'au plan de l'expression religieuse des élèves - il faut souligner d'entrée de jeu que les écoles, en Europe, sont profondément sécularisées dans leurs programmes, leurs objectifs et leurs méthodes aussi bien qu'à travers leurs personnels et leurs élèves”. J.-P. Willaime, Introduction, [w:] Des maîtres et des dieux - écoles et religions en Europe, ed. J.-P. Willaime, Paris 2005, s. 7. 
płynące ze strony Kościoła"46. Trzeba zauważyć, że czym innym jednak jest laicyzacja szkoły niejako „od wewnątrz” obecna w przekonaniach uczniów i personelu, a czym innym wprowadzana „od zewnątrz”, czyli poprzez przepisy i programy nauczania. $Z$ tą drugą z pewnością mamy do czynienia w Polsce, czego dowodem jest eliminacja religii z ramowych planów nauczania ${ }^{47}$ czy też próby wprowadzania ideologii gender ${ }^{48}$. Niemniej Kościół pozostaje autonomiczny w zakresie treści przekazywanych w ramach szkolnej lekcji religii i realizowanych w szkole zadań wychowawczych, wynikających z podstawy programowej katechezy.

Zostało bowiem wykazane powyżej, że wychowanie do życia wspólnotowego realizowane w ramach szkolnej lekcji religii przygotowuje do podjęcia zadań we wspólnotach naturalnych. W szczególny zaś sposób pogłębia poczucie przynależności do wspólnoty Kościoła i ma także na celu budzenie nowych więzi ze wspólnotą kościelną (por. PDK 28). Ten kulminacyjny cel pojawia się wśród wymagań ogólnych czwartego etapu edukacyjnego, gdzie podstawa programowa katechezy wymienia socjalizację kościelną rozumianą jako odkrycie przez ucznia swojego miejsca i zadań w Kościele, wynikających z przyjętego sakramentu bierzmowania ${ }^{49}$. Wydaje się jednak, iż w odróżnieniu od wcześniejszych etapów edukacyjnych, począwszy od trzeciego etapu edukacyjnego (gimnazjum) wymagania szczegółowe związane z zadaniem wychowania do życia wspólnotowego dotyczą bardziej przekazu treści nauczania (historii Kościoła i relacji państwo-Kościół) niż postaw i działań wychowawczych. Na te ostatnie z kolei trzeba położyć nacisk, by szkolne lekcje religii rzeczywiście budowały lub pogłębiały poczucie przynależności do wspólnoty kościelnej (por. PDK 28).

Zrozumiałe jest, że oddziaływanie katechetyczne staje się jałowe, jeśli nie ma odniesienia do konkretnej wspólnoty wierzących. „Grupa chrześcijańska, oprócz tego, że jest czynnikiem dydaktycznym, jest wezwana do tego, aby być doświadczeniem wspólnot i formą uczestniczenia w życiu eklezjalnym, znajdując w szerszej wspólnocie eucharystycznej swój cel i swój pełny wyraz" (DOK 159). W tym kontekście wydaje się dość oczywiste, że wysiłki katechetów winny zmierzać do tworzenia (na ile to możliwe) niezbędnej więzi z uczniami oraz uczniów pomiędzy

${ }^{46}$ Por. K. Misiaszek, Koncepcja nauczania religii katolickiej..., dz. cyt., s. 209.

${ }^{47}$ Por. Rozporządzenie MEN z dnia 7 lutego 2012 r. w sprawie ramowych planów nauczania w szkołach publicznych, Dz.U. z 22 lutego 2012 r., poz. 204.

${ }^{48}$ Pod hasłem zwalczania stereotypowych ról płciowych powstały wytyczne programowe dla pracy z dziećmi w przedszkolu. Por. A. Dzierzgowska, J. Piotrowska, E. Rutkowska, Równościowe przedszkole. Jak uczynić wychowanie przedszkolne wrażliwym na płeć?, www.maleprzedszkola.pl/ content/download/22683/72769/file/ (30.08.2013). Por. także na ten temat: Odpowiedź podsekretarza stanu w Ministerstwie Edukacji Narodowej - z upoważnienia ministra - na interpelacje nr 17650 w sprawie programu „Równościowe przedszkole”, www.sejm.gov.pl/sejm7.nsf/InterpelacjaTresc. xsp?key=21FB6D9D (1.09.2013).

${ }^{49}$ Por. PPK, s. 72. 
sobą w ramach lekcji religii. Grupa chrześcijan oddziałuje swym sposobem myślenia i działania na pozostałe osoby tworzące społeczność szkolną, a punktem docelowym ich działań jest wspólnota eucharystyczna, czyli spotkanie przy stole Słowa i Ciała Pana. Tworzenie „wspólnoty katechetycznej” w środowisku szkolnym ma zarazem wykraczać poza nie, znajdując swe urzeczywistnienie we wspólnotach parafialnych. Szkolna katecheza staje się w ten sposób wyrazem troski o duchowy rozwój uczniów. Nie chodzi zatem wyłącznie o to, by uczęszczający na lekcję religii wraz z nauczycielem tworzyli jedynie wspólnotę nauczania - uczenia się. Ich wspólny wysiłek będzie miał charakter prawdziwie katechetyczny, o ile na horyzoncie dążeń pojawi się budowanie wspólnoty wiary ${ }^{50}$.

Skuteczność oddziaływania katechetycznego jest ściśle powiązana z właściwym kształtem wspólnoty Kościoła, która staje się punktem odniesienia dla katechizowanych. „Konkretnie więc wspólnota chrześcijańska staje się widzialnym miejscem świadectwa wiary, troszczy się o formację swoich członków, przyjmuje ich jako rodzina Boża, starając się o to, by być żywym i stałym środowiskiem wzrostu wiary" (DOK 158). Wspólnota staje się wzorcem dla jednostki w przeżywaniu i pogłębianiu swej wiary. Osoba - jednostka - wchodzi w ten styl życia chrześcijańskiego, który prezentuje konkretna wspólnota chrześcijan. Na tym polega socjalizacja religijna, która, połączona $\mathrm{z}$ formacją proponowaną przez tę wspólnotę, staje się w pełnym tego słowa znaczeniu wychowaniem religijnym. Dzieje się tak zwłaszcza w czasie przygotowania do przyjęcia sakramentów ${ }^{51}$. „Katecheza szkolna potrzebuje [...] zaplecza rodzinnego i kościelnego, wytwarzającego odpowiedni klimat katechetyczny" ${ }^{52}$.

Katecheza jest wyjątkowym procesem wychowawczym, stosującym zasadę ważną dla ewangelizacji: ewangelizować wychowując i wychowywać ewangelizując (por. DOK 147). Zasada ta nakłada na katechezę zobowiązanie do pobudzania, świadczenia pomocy wychowankom i prowadzenia wszelkiej działalności mającej na celu ich osobisty rozwój, otwartość na wartości oraz kształtowanie umiejętności właściwego wyboru ${ }^{53}$. Wiąże się zatem ściśle z programem wychowawczym szkoły, wprowadzając w zadania podejmowane we wspólnotach naturalnych, ale i wykracza poza ów program, dążąc do zakorzenienia we wspólnocie wiary i prezentując chrześcijańską koncepcję człowieka.

Podsumowując wzajemne związki programu wychowawczego polskiej szkoły i zadań stawianych przed katechezą w kontekście wychowania do życia

\footnotetext{
${ }^{50}$ Por. T. Panuś, Jaka katecheza dla współczesnego człowieka?, dz. cyt., s. 432.

${ }^{51}$ Por. A. Fyda, A. Kielian, Nowelizacja podstawy programowej katechezy, [w:] Katecheza w Roku Kapłańskim. Materiaty z Sierpniowych Dni Katechetycznych w Archidiecezji Krakowskiej w roku 2009, red. T. Panuś, Kraków 2009, s. 61n.

${ }^{52}$ T. Panuś, Jaka katecheza dla współczesnego człowieka?, dz. cyt., s. 433.

${ }^{53}$ Por. E. Alberich, Katecheza dzisiaj, dz. cyt., s. 146n.
} 
wspólnotowego, można stwierdzić, że istnieje pomiędzy nimi istotna zbieżność celów i relacja wzajemnego dopełniania. „«Demokratyczne państwo prawa karmi się etosem swoich obywateli» - nie może samo stworzyć ich «kultury etycznej», lecz zakłada jej istnienie" ${ }^{4}$. Zakładane w dokumentach programowych polskiej szkoły i szkolnego nauczania religii cele, jak: tworzenie i umacnianie lokalnych wspólnot, zakorzenienie uczniów we wspólnotach naturalnych, takich jak rodzina i naród, budowanie klimatu do dialogu pomiędzy przedstawicielami różnych kultur i przekonań, stanowią niezbędny warunek trwałości wspólnoty państwa. Szkolna lekcja religii wpisuje się $\mathrm{w}$ realizację programu wychowawczego polskiej szkoły oraz działa na rzecz tworzenia i wzmacniania wspólnot, które skupiają jednostki o podobnych przekonaniach i podzielających wspólne wartości. Przyczynia się do osiągnięcia konsensusu w ramach kształtowania podstaw przy konstruowaniu programu wychowawczego szkoły. Niektóre zaś cele i zadania wychowawcze podstawy programowej katechezy z 2010 roku dopełniają wymagania ogólne podstawy programowej kształcenia ogólnego z 2009 roku. Wśród nich trzeba wymienić: kształtowanie chrześcijańskiego systemu wartości, kształtowanie tożsamości religijnej wychowanków oraz ich socjalizację w ramach wspólnoty religijnej. Zadanie wychowania do życia wspólnotowego stawiane przed katechezą wykracza również poza program szkolny. Domaga się dopełnienia w działalności pozaszkolnej, aby doprowadzić wychowanków do wspólnoty eucharystycznej i aktywnego uczestnictwa w życiu i działalności Kościoła. Nie stoi to jednak w opozycji do celów wychowania w polskiej szkole. Realizacja zadań katechezy w środowisku szkolnym, jak i poza nim sprzyja bowiem tworzeniu właściwego klimatu dla wychowania dzieci i młodzieży oraz pozwala na szeroko rozumianą współpracę w zakresie kształtowania ich tożsamości indywidualnej i zaangażowania na rzecz wspólnoty. W swej warstwie eklezjotwórczej umacnia i buduje lokalną wspólnotę Kościoła zjednoczoną wokół Chrystusa.

\section{Summary}

\section{Education for Community Life as a Task of School Religion Education in the Light of Educational and Catechetical Regulations in Poland}

Upbringing is a task of both school education and catechesis. The purpose of this article is to answer the following questions: do the general aims of school education in Poland go hand in hand with the tasks of catechesis? To what extent it is possible to educate for community life (cf. GDC 86) at school religion classes in Poland? In order to find answers to these questions it is necessary to present the aims of general education in Poland according to the new core curriculum (based on the Regulation by the Minister of National Education of 23 December 2008 on Core Curricula for Pre-school and General Education in particular types of schools) along with methods for entering its records into school curricula.

${ }^{54}$ W. Brezinka, Wychowanie i pedagogika w dobie przemian..., dz. cyt., s. 32. 
The general aims of upbringing, that the documents of the Church put before religious instruction at school are shown against this background, in order to find points of contact with the school curricula. The possible implementation of education for community life in the school environment is discussed on the base of the Core Curriculum for the Catechesis of the Catholic Church in Poland (approved by the Polish Bishops' Conference in 2010).

In conclusion it can be stated that the aims of both religion education at school and general education in Poland, in relation to education for community life, are similar: creation and strengthening of local communities, rooting students in natural communities, such as the family and the nation, creating a climate for dialogue between representatives of different cultures and beliefs. All these aims are focused on development of attitudes necessary for the sustainability of the community of the state. Furthermore, education for community life as the task of catechesis goes beyond the scope of school education. It calls for completion in extracurricular activities, to bring pupils to the Eucharistic community and active participation in the life and activities of the Church.

\section{Keywords}

Poland, education, curriculum, catechesis, community life 
